\title{
Compulsory maintenance of the Land Register: an exception to the fundamental principle of a conclusive register underpinning the Land Registration Act 2002*
}

[Unpublished paper submitted to the UK journal The Conveyancer \& Property Lawyer for possible publication]

\section{M Park ${ }^{\dagger}$}

\begin{abstract}
The experience of the then Australian colonies in introducing land title registration in the nineteenth century provides a vantage point to observe and provide commentary on the recently enacted Land Registration Act 2002. The author offers the observation that the legislative draftsperson has, perhaps inadvertently, included an exception to what the Law Commission described as 'the fundamental principle' of a land registration system, that of the conclusive register wherein interests not recorded in the register have no legal effect. Thus, pursuant to the adverse possession provisions of the Act, it is possible for a trespasser or squatter to acquire an unassailable title to registered land without that title being disclosed on the register. The conclusion, based on the Australian experience, is that the advantages of registered title land are insufficient to overcome the inertia of interest holders and mandatory participation in the registered title system is essential for the integrity of the register.
\end{abstract}

\section{INTRODUCTION}

In 2002 the English Parliament passed the Land Registration Act 2002 coming into effect in October 2003. The Act was the consequence of recent investigation and reports by the Law Commission and Her Majesty's Land Registry at the turn of the century. The investigation and reports were the culmination of many such reports into the operation of the 1925 Land Registration Act.

The experience of the Australian land title registries is that voluntary or permissive rights are insufficient to enable the maintenance of a complete comprehensive and conclusive register and it is necessary to impose a compulsory duty upon interest holders to utilise the rights of registration available to such interest holders. In the absence of a positive duty imposed upon such interest holders there exists the possibility of unrecorded legal interests existing outside the register which defeats the purpose of such a register. 


\section{THE AUSTRALIAN EXPERIENCE}

All the Australian colonies (and New Zealand) introduced land title registration in the latter half of the nineteenth-century. The successful introduction and later adoption throughout the world despite opposition from the conveyancing profession is evidence of the innate advantage of the system wherein title is founded upon registration and registration alone ${ }^{1}$ — the "fundamental principle" of land title registration.

One of the features of the nineteenth-century Australian schemes was the voluntary participation in the title registration system: that is, except for future Crown grants which could only be made pursuant to title registration, the holders of existing "unregistered" (or general law or old law) land were under no compulsion to bring their holdings into the title registration system.

With the clarity of vision usually only associated with hindsight, this policy was mistaken. This writer offers, as conjecture only, the suggestion that the policy of voluntary conversion was adopted to disarm the opponents of land title registration and because of a confidence that the benefits and advantages of registration were so readily apparent that there was no need for added incentives or compulsion to bring unregistered land into the new system. Now, some one hundred and fifty years later, the time for patiently awaiting the self-interest of holders of unregistered land to motivate conversion has passed. The expense of maintaining two registers (a title register for registered land and a register of deeds for unregistered land evidencing each and every transaction) has brought about recent policy changes for the compulsory conversion of land outside the registered land system.

In addition to unregistered land remaining outside the register, there was provision for unrecorded overriding interests associated with registered land notwithstanding that these interests could not be discerned by inspecting the register: the raison d'être of land title registration. Thus, in the jurisdictions of Victoria and Western Australia (and Tasmania in the years 1980 to 2001) the interests of a squatter founded upon adverse possession were similar to those of the English squatter pursuant to $\S 70(1)$ (iv) of the English Land Registration Act 1925. 
The other title registration jurisdictions which permit adverse possession (including the Canadian province of Alberta) usually require the squatter to apply for and be entered in the register as the proprietor in order to "perfect" the title acquired by adverse possession. Consequently the distinction is that in Victoria and Western Australia, adverse occupation for the statutory period alone is sufficient to acquire title while the other jurisdictions require an application for registration to be made with adverse occupation for the statutory period being a condition precedent to the squatter's application for registration. These latter jurisdictions do not offend against the fundamental principle (of title founded upon registration and registration alone) because the title acquired through adverse possession requires "perfecting" by registration and is of no effect until perfected by registration.

A perhaps unintended consequence in those jurisdictions recognizing unrecorded overriding interests is that if the adverse occupier of part of the adjoining parcel does not apply for registration, the dispossessed registered proprietor is left with the residue of his holding with a "clouded" title and is unable to clear that title. This impediment was the subject of a written submission to the Victorian Parliamentary Law Reform Committee Inquiry into the Fences Act. ${ }^{2}$

The provisions enabling the adverse occupier to apply to be entered in the register as the registered proprietor do not extend to allowing the dispossessed registered proprietor to apply to have the occupier entered in the register as the registered proprietor. This may be contrasted with those jurisdictions allowing for inadvertent encroachments by permitting the encroaching landholder or the holder of the parcel encroached upon to apply to the court for relief (emphasis added). Again, relying on conjecture, I suggest that the framers of the statute failed to consider the problem arising from the squatter failing to apply to be entered in the register because of the perceived self-interest of the squatter being to so apply. It is small consolation for the dispossessed proprietor with a clouded title to be advised that the title (to the residue of the holding) can be cleared by initiating a costly and unsuccessful legal suit against the squatter which will result in a court order requiring the registrar to remove the adversely occupied land from the dispossessed proprietor's registered title land holding. 


\section{THE ENGLISH REFORMS OF 2002}

The 2002 English Land Registration Act purported to do away with this anomaly of unrecorded title founded upon adverse possession (dating from the 1925 LRA) by requiring the squatter to apply for registration after ten years adverse possession and to be so registered in the absence of an objection by the dispossessed registered (or "true" or "documentary" or "paper") proprietor. Such registration would confer title upon the applicant squatter and extinguish the dispossessed registered proprietor's title.

Where the dispossessed registered proprietor objects to the squatter's application that proprietor has two years to bring suit to eject the squatter and, upon failing to do so, a further application by the squatter after the two additional years will be granted notwithstanding any objection by the dispossessed registered proprietor. ${ }^{3}$ This 2002 procedure is a modification of that introduced into South Australia in 1945 and later adopted by Queensland (1952) and New Zealand (1963). This writer suggests that the statute passed by the Parliament in 2002 has, perhaps inadvertently, allowed for the squatter to acquire unimpeachable title over registered land without this unimpeachable title being disclosed in the register. This would be an exception to the "fundamental principle of a conclusive register which underpins" the 2002 Act. Again, it is suggested that this inadvertent omission is a consequence of the perceived self-interest of the squatter being sufficient motivation for the squatter to apply for registration.

\section{THE PERCEIVED ANOMOLY}

Consider the squatter who has been in adverse occupation of a registered title land parcel for a period in excess of ten years. Pursuant to the 2002 Act the squatter applies to the Registrar to be entered into the register as the registered proprietor thus acquiring the title and extinguishing the title of the dispossessed registered proprietor. The Registrar, as required by the Act, notifies various interested persons including the dispossessed registered proprietor. The dispossessed registered proprietor then lodges an objection and as a consequence the squatter's application is disallowed.

Thereafter the further two-year period permitting the registered proprietor to commence proceedings against the squatter begins to run. If at the end of the further two-year period the dispossessed registered proprietor has not commenced proceedings against the squatter and the squatter has remained in adverse occupation of the parcel then the 
squatter may make a further application to be registered which must be granted as of right.

Consider however the case where the squatter is empowered by the Act to make the further application to be registered which must be granted as of right but, for whatever reason, neglects or declines to make that further application. What is the legal status of the squatter vis à vis the dispossessed registered proprietor? What is the legal status of the squatter vis à vis the Registrar and the rest of the world?

It is submitted that the squatter has acquired an unassailable legal title that cannot be challenged by the Registrar or the dispossessed proprietor or anyone else. This is so even though the register fails to disclose this unassailable title held by the squatter. The squatter has obtained an unassailable legal title without extinguishing that of the dispossessed registered proprietor who apparently retains the registered title, which title is now inferior to that acquired by the squatter. The only title readily discernible to the prudent inspector of the register is that of the dispossessed registered proprietor who is recorded as the registered proprietor.

One person possibly able to challenge the squatter's unassailable off-register title is the manager of the local bank or other financial institution. If requested to provide finance or a loan upon the security of the squatter's unassailable unregistered title this may prove to be too far outside the institution's experience or expertise with the consequence that the institution refuses to provide finance despite the security of the squatter's unassailable title. The fastidiously prudent requirements of such a financial institution may provide the necessary impetus for the squatter to "regularize" the register entry that is absent from the 2002 Act.

It is conceded that the likelihood of a squatter who has made an initial but rejected ten year application failing to follow through with the further application upon the passing of the further two year period may be small. However, the Act makes provision for another similarly small likelihood. That is the case where the dispossessed registered proprietor who has objected to the initial ten-year application also fails to follow through with the commencement of proceedings against the squatter within the next two years. 


\section{CONCLUSION}

As a mere colonial from a jurisdiction that has long endured the oddities and anomalies of the registered land title system in Victoria the writer is reluctant to proffer advice to his English cousins. However, his view is that the proper operation of any land registration system requires the upholding of the necessary maintenance of a complete, comprehensive, and conclusive register as a primary consideration.

A suggested solution is that at some time, say three years (or some other suitable period) after the initial disallowance of the squatter's first application upon the dispossessed registered proprietor's objection, the squatter's failure to follow through with the expected further application should result in the parties (the dispossessed registered proprietor and the squatter) being restored to their positions prior to the squatter's first application. Thus any further application by the squatter after the passing of the suggested three years would be processed as an initial application subject to the registered proprietor's objection with the consequence that this unpunctual further application by the squatter will not be granted as of right.

"The writer acknowledges the advice and contributions from the members of the

Centre for Spatial Data Infrastructures and Land Administration in the

Department of Geomatics at the University of Melbourne, particularly Ian

Williamson, Professor of Surveying and Land Information, and Jude Wallace, Senior Research Fellow.

$\dagger$ One time graduate research scholar, Department of Geomatics, University of Melbourne.

${ }^{1}$ Law Commission and Her Majesty's Land Registry, Land Registration for the Twenty-first century: a conveyancing revolution (Land Registration Bill and Commentary (2001), page 4, I[ 1.10, The Stationary Office, London.

[URL: http://www.lawcom.gov.uk/library/lc271/lc271.pdf viewed 23 July, 2004.]

${ }^{2}$ Victorian Parliamentary Law Reform Committee, Review of the Fences Act 1968 Report (1998), page 148, II 6.64, Parliament of Victoria, Melbourne.

[URL: http://www.parliament.vic.gov.au/lawreform/fences/masterdocument.pdf viewed 30 July, 2004.]

${ }^{3}$ Schedule 6 of the Land Registration Act 2002. 


\section{University Library}

\section{- M M N E R VA A gateway to Melbourne's research publications}

Minerva Access is the Institutional Repository of The University of Melbourne

Author/s:

Park, M. M.

Title:

Compulsory maintenance of the Land Register: an exception to the fundamental principle of a conclusive register underpinning the Land Registration Act 2002

Date:

2004

Citation:

Park, M. M. (2004) Compulsory maintenance of the Land Register: an exception to the fundamental principle of a conclusive register underpinning the Land Registration Act 2002.

Publication Status:

Unpublished

Persistent Link:

http://hdl.handle.net/11343/34893 